\title{
Detection of multidrug-resistant Enterobacteriaceae isolated from river waters flowing to the Guanabara Bay and from clinical samples of hospitals in Rio de Janeiro, Brazil
}

\author{
Verônica Dias Gonçalves ${ }^{1}$, Frederico Meirelles-Pereira², Márcio Cataldo', Bianca de \\ Oliveira Fonseca ${ }^{1}$, Barbara Araujo Nogueira ${ }^{1}$, Julianna Giordano Botelho Olivella ${ }^{1}$, \\ Francisco de Assis Esteves ${ }^{2}$, Ana Luiza Mattos-Guaraldi ${ }^{1}$, Arnaldo Feitosa Braga de \\ Andrade $^{1}$, Alexandre Ribeiro Bello ${ }^{1}$, José Augusto Adler Pereira ${ }^{1}$
${ }^{1}$ Departamento de Microbiologia, Imunologia e Parasitologia, Faculdade de Ciências Médicas, Universidade do Estado do Rio de Janeiro, Rio de Janeiro, Brasil
${ }^{2}$ Laboratório de Limnologia, Departamento de Ecologia, Centro de Ciências da Saúde, Universidade do Estado do Rio de Janeiro, Rio de Janeiro, Brasil

Introduction: The use of antibiotics in humans, animal husbandry and veterinary activities induces selective pressure leading to the colonization and infection by resistant strains. Objective: We evaluated water samples collected from rivers of the Guanabara Bay, which have suffered minor and major environmental degradation, and clinical samples of hospital origin to detect evidence of the presence of resistance genes to aminoglycosides, beta-lactam antibiotics and fluoroquinolones in strains of Klebsiella pneumoniae subsp. pneumoniae, K. pneumoniae subsp. ozaenae and Escherichia coli.

Materials and methods: For isolation of the water strains we employed culture media containing $32 \mu \mathrm{g} / \mathrm{ml}$ cephalotin and $8 \mu \mathrm{g} / \mathrm{ml}$ gentamicin. The strains from clinical materials were selected using culture media containing $8 \mu \mathrm{g} / \mathrm{ml}$ gentamicin. The strains were identified and subjected to antimicrobial susceptibility testing (AST), plasmid DNA extraction and polymerase chain reaction (PCR) to detect genes encoding enzymes modifying aminoglycosides (EMA), extended-spectrum beta-lactamases (ESBL) and plasmid mechanisms of quinolone resistance (PMQR).

Received: 05/04/18

Accepted: $24 / 10 / 18$

Published: $13 / 12 / 18$

Citation:

Dias-Gonçalves V, Meirelles-Pereira F, Cataldo M, de Oliveira-Fonseca B, Araujo-Nogueira B, BotelhoOlivella JG, et al. Detection of multidrug-resistant Enterobacteriaceae isolated from river waters flowing to the Guanabara Bay and from clinical samples of hospitals in Rio de Janeiro, Brazil. Biomédica. 2019;39(Supl.1):135-49

https://doi.org/10.7705/biomedica.v39i0.4391

Corresponding author:

Verônica Dias Gonçalves, Departamento de Microbiología, Inmunología y Parasitología, Facultad de Ciencias Médicas, Universidade do Estado do Rio de Janeiro, Av. Professor Manuel de Abreu, 444/3은 andar, CEP: 20550-170, Rio de Janeiro, RJ, Brasil Teléfono: (+55) (21) 2868 8280; fax: (+55) (21) 2868 8376

kaiura@bol.com.br

\section{Author contributions:}

The manuscript was drafted from the development of the doctoral thesis of Verônica Dias Gonçalves, who had the guidance and cooperation of the other ten authors regarding data analysis and interpretation, writing, critical review, and final approval of this version. All authors are responsible for the accuracy and completeness of the information analyzed.

\section{Funding:}

This research was supported by grants from the Conselho Nacional de Desenvolvimento Científico e Tecnológico (CNPq), Brazil; Fundação de Apoio a Pesquisa do Estado do Rio de Janeiro (FAPERJ), Brazil, and Coordenação de Aperfeiçoamento de Pessoal de Nível Superior (CAPES), Brazil.

Conflict of interest

Authors declare no conficts of interest.
Results: The AST of the isolates recovered from water samples showed multidrugresistance profiles similar to those found in isolates recovered from clinical materials. All isolates from water samples and $90 \%$ of the isolates from clinical samples showed at least one plasmid band. In the PCR assays, $7.4 \%$ of the isolates recovered from water samples and $20 \%$ of those from clinical materials showed amplification products for the three antimicrobial classes.

Conclusion: We believe that the detection of microorganisms presenting genetic elements in environments such as water is necessary for the prevention and control of their dissemination with potential to infect humans and other animals in eventual contact with these environments.

Keywords: Klebsiella pneumoniae; Escherichia coli; drug resistance, multiple; plasmids; waste water; Brasil.

Detección de enterobacterias multirresistentes aisladas en aguas de los ríos que desembocan en la bahía de Guanabara y en muestras de hospitales de Río de Janeiro, Brasil

Introducción. El uso de antibióticos en seres humanos, en la industria pecuaria y en las actividades veterinarias induce una presión selectiva que resulta en la colonización e infección con cepas resistentes.

Objetivo. Determinar la presencia de genes de resistencia a aminoglucósidos, betalactámicos y fluoroquinolonas en cepas de Klebsiella pneumoniae subsp. pneumoniae, K. pneumoniae subsp. ozaenae y Escherichia coli, obtenidas de muestras de agua de los ríos que desembocan en la bahía de Guanabara y de muestras clínicas de hospitales de Río de Janeiro. Materiales y métodos. En la selección de las cepas resistentes obtenidas de las muestras de agua de los ríos, se emplearon medios de cultivo que contenían $32 \mu \mathrm{g} / \mathrm{ml}$ de cefalotina y $8 \mu \mathrm{g} /$ $\mathrm{ml}$ de gentamicina. En el caso de las muestras de especímenes clínicos, se usaron medios de cultivo que contenían $8 \mu \mathrm{g} / \mathrm{ml}$ de gentamicina. Las cepas se identificaron y se sometieron a pruebas de sensibilidad antimicrobiana, extracción de ADN plasmídico y pruebas de reacción en cadena de la polimerasa (PCR) para detectar los genes que codifican aquellas enzimas que modifican los aminoglucósidos, las betalactamasas de espectro extendido (BLEE) y los mecanismos de resistencia a las quinolonas mediados por plásmidos. 
Resultados. Se encontraron perfiles de resistencia a los antimicrobianos similares en los dos grupos. En todas las bacterias obtenidas de las muestras de agua y en $90 \%$ de las muestras clínicas, se evidenciaron bandas de plásmidos asociados con la transferencia de genes de resistencia. En las pruebas de PCR, se obtuvieron productos de amplificación de los genes de resistencia para las tres clases de antimicrobianos analizados, en el 7,4\% de las bacterias recuperadas de las muestras de agua y en el $20 \%$ de aquellas recuperadas de las muestras clínicas.

Conclusión. La detección de microorganismos con elementos genéticos que confieren resistencia a los antibióticos en ambientes como el agua, es una estrategia necesaria para prevenir y controlar la diseminación de estos agentes patógenos con potencial para infectar a humanos y a otros animales en dichos ambientes.

Palabras clave: Klebsiella pneumoniae; Escherichia coli; resistencia a múltiples medicamentos; plásmidos; aguas residuales; Brasil.

It is well known that the use of broad-spectrum antibiotics such as aminoglycosides, third- and fourth-generation cephalosporins, and fluoroquinolones allows selecting opportunistic multidrug-resistant bacteria which can colonize inpatients and, in some cases, cause serious infection difficult to treat $(1,2)$. As in many warm-blooded animals, human intestine is known to harbor bacteria capable of causing infections in hospitals and in the community $(3,4)$.

In the natural environment, the selection of multidrug-resistant bacteria may occur due to the production of antibiotic compounds by soil bacteria, but also due to discharges of human and animal feces that may contain antimicrobial drug residues $(5,6)$. Some resistance encoding genes may be chromosomal housekeeping genes involved in the bacterium own protection against the antimicrobial compounds they produce by themselves or by other bacteria in the surrounding environment $(6,7)$.

Additionally, some antimicrobial drugs are still used in animal farms and aquaculture as growth promoters and as prophylactic agents, which can also cause an artificial selection of antimicrobial-resistant bacteria (8-10). The use of antimicrobial drugs in humans, animal husbandry and veterinary care may enable the selection of bacterial strains with potential resistance traits resulting in host colonization and infection by different bacteria, such as those belonging to the Enterobacteriaceae family. This event may result in the appearance of bacteria with different resistance profiles which challenge treatment $(11,12)$.

Another major concern is the existence of mobile genetic elements in some bacteria such as plasmids, gene cassettes, and transposons that can assemble blocks of resistant genes and transfer them horizontally enabling other bacteria to acquire genes encoding for resistance mechanisms to several antimicrobial drugs (13-15).

The ecosystem of several bodies of water has been seriously compromised by human practices and lifestyle. The discharges of households, hospitals and industrial residues without previous appropriate treatment have added to the problematic of bacterial antimicrobial resistance dissemination throughout these environments, which are used by humans and animals in many ways: for sports, professionally or for survival, users who may become colonized or infected by resistant bacteria (16-18).

Guanabara Bay is the second largest bay in Brazil (with $380 \mathrm{~km}^{2}$ ); it runs all along Rio de Janeiro urban cost line and has suffered intense degradation for many years due to population growth and industry development (19). Among the consequences of the degradation suffered by the accumulation of waste and sewage in these areas, we can mention the floods during heavy rain periods and the diseases caused by various microorganisms they brought with them. 
In a previous study, Meirelles-Pereira, et al., detected the presence of strains of multidrug-resistant bacteria in sewage samples from a hospital in Rio de Janeiro, as well as from coastal lagoons in the city (20). The presence of extendedspectrum beta-lactamases (ESBL) and enzymes modifying aminoglycosides (EMA) was confirmed by phenotypic and PCR assays (data not shown).

The purpose of this work was to identify specific genes encoding EMA, $\mathrm{ESBL}$, and plasmid mechanisms of quinolone resistance (PMQR) in Klebsiella pneumoniae subsp. pneumoniae, Escherichia coli, and K. pneumoniae subsp. ozaenae strains, which were isolated from Guanabara Bay water samples and hospital waste to better understand the dissemination of resistant mobile genetic elements in the natural environment and in hospital settings.

\section{Materials and methods}

\section{Study area}

The Guapimirim River, which is part of the Magé Channel, supplies the municipalities of São Gonçalo and Niterói and is located on the northern coast of the hydrographic region of the Guanabara Bay where the best preserved rivers are located (19).

The Guaxindiba River, located on the eastern coast, is born in São Gonçalo and it traverses part of the largest preserved mangrove area of the Guanabara Bay (the Guapimirim Environmental Protection Area) before discharging into the bay in its lower section. Large masses of sewage and other waste produced by the population inhabiting its surroundings are deposited in its waters through tributaries contributing to the degradation of the mangroves.

The Caceribu River is one of the main contributors to the Guanabara Bay. With almost $60 \mathrm{~km}$ of extension, its springs originate in the mountains of Rio Bonito and Tanguá municipalities and flow on the eastern slope of the Guanabara Bay through the Guapimirim mangrove (19).

The Mangue Channel on the western coast and its tributaries run through the most densely populated areas and they receive large quantities of treated and untreated sewage and residues including antimicrobials from industries and surrounding residential areas. The waters in the region comprising the Channel between Governor and Fundão Islands and the mainland have the worst quality, with high concentrations of nutrients such as phosphorus and nitrogen, as well as fecal coliforms, and a low concentration of oxygen due to the releases of raw or partially treated effluents from industrial and residential areas located north of Rio de Janeiro (19).

\section{Strain selection}

We studied 37 strains: 26 of E. coli, nine of K. pneumoniae subsp. pneumonia, and two of $K$. pneumoniae subsp. ozaenae. These strains were isolated from water collected in rivers that flow into the Guanabara Bay and from clinical specimens collected at a university hospital in Rio de Janeiro.

Environmental samples were collected at Guapimirim, Caceribu, and Guaxindiba Rivers and in the Magé Channel (Guapimirim Environmental Protected Area - Magé, RJ) in April, 2009 (figure 1). We also collected samples from two different areas of the Fundão Island rivers, from Bica beach (Governador Island), and the Mangue Channel in July, 2009. Regarding 
clinical samples, the criterion for selection was growth in selective media. Residues of hospital origin containing antimicrobials and microorganisms are continuously released into aquatic receptacles contaminating the environment and favoring the dissemination of transferable resistance markers between the microorganisms.

\section{Isolation of strains from clinical material}

Strains of $K$. pneumoniae and $E$. coli from different clinical materials collected and analyzed in the bacteriology laboratory of the university hospital between May and July, 2010, were inoculated in eosin methylene blue agar (EMB) (Oxoid) containing $8 \mu \mathrm{g} / \mathrm{mL}$ of gentamicin (Sigma) and those with positive growth were selected for the study.

\section{Isolation of strains from water samples}

Sterile flasks were used to collect the water samples, which were then transported on ice to the laboratory in the next six hours and tested straight after arrival according to the Environmental Protection Agency (EPA) protocols (21). A selection criteria was resistance to gentamicin as for the clinical samples, but also resistance to cephalotin, the latter determined by adding $32 \mu \mathrm{g} / \mathrm{mL}$ of cephalotin (Sigma) into the EMB media. The collection was done during low tide to determine the effect of higher hydrolytic pressure in the drained areas under study. The strains with macroscopic characteristics compatible with the bacterial species of interest were identified according to Winn, et al. (22).

\section{Antimicrobial susceptibility tests}

The antimicrobial susceptibility tests (AST) was carried out using the agar diffusion method according to the Clinical Laboratories Standards Institute (CLSI) (23). Escherichia coli strain ATCC 25922 was used as control.

The following antimicrobial agents (Oxoid) were used with their respective potencies: Cotrimoxazol (Sut- $25 \mu \mathrm{g})$, cephalotin (Cph- $30 \mu \mathrm{g})$, ceftazidime (Caz- $30 \mu \mathrm{g}$ ), cefoxitin (Fox- $30 \mu \mathrm{g}$ ), cefotaxime (Ctx- $30 \mu \mathrm{g})$, cefuroxime (Crx$30 \mu \mathrm{g}$ ), ceftriaxone (Cro- $30 \mu \mathrm{g}$ ), cephazoline (Cfz- $30 \mu \mathrm{g}$ ), aztreonam (Atm$30 \mu \mathrm{g})$, ertapenem (Etp- $10 \mu \mathrm{g})$, imipenem (Ipm- $10 \mu \mathrm{g})$, cefepime (Cpm- 30 $\mu \mathrm{g}$ ), piperacillin/tazobactam (Ppt- 100/10 $\mu \mathrm{g}$ ), amoxillin/clavulanic acid (Amc20/10 $\mu \mathrm{g}$ ), ampicillin/sulbactam (Asb- 10/10 $\mu \mathrm{g}$ ), chloramphenicol (Chl- 30 $\mu \mathrm{g}$ ), ciprofloxacin (Cip- $5 \mu \mathrm{g}$ ), norfloxacin (Nor- $10 \mu \mathrm{g}$ ), tetracycline (Tet- 30 $\mu \mathrm{g}$ ), ampicillin (Amp- $10 \mu \mathrm{g}$ ), gentamicin (Gen- $10 \mu \mathrm{g}$ ), amikacin (Ak- $30 \mu \mathrm{g}$ ), kanamycin (Kan- $30 \mu \mathrm{g})$, tobramycin (Tob- $10 \mu \mathrm{g})$.

\section{Phenotypic detection of ESBL}

The isolates resistant to second and third cephalosporin's generation in AST were submitted to confirmatory tests of ESBL production by the doubledisc synergy test and the approximation test following the CLSI standards (24). Klebsiella pneumoniae strain ATCC 700603 was used as the test control.

\section{Plasmid extraction}

Plasmid DNA alkaline extraction was performed on all strains following Gonçalves, et al. (25). The strains were subjected to electrophoresis in $0.8 \%$ agarose gel (Sigma) for plasmid detection. We used the E. coli R861 strain plasmid DNA as weight marker and the E. coli K12 R23 as the negative control. 


\section{Gene detection by PCR}

PCR was performed using primers compatible with ESBL, EMA, and $\mathrm{PMQR}$ in all K. pneumoniae subsp. pneumoniae, K. pneumoniae subsp. ozaenae, and E. coli strains resistant to any antimicrobial drug tested in the AST following the work developed by Arlet, et al. (26), Pitout, et al. (27), van de Klundert, et al. (28), and Jiang, et al. (29).

Isolates showing resistance to carbapenems were sent to the Healthcare Associated Infections Laboratory (LAPIH) of the Oswaldo Cruz Institute (Fiocruz) for the identification of the bla ${ }_{K P C}$ gene according to Yigit, et al. (30).

The thermal cycling conditions were performed in a Cetus model 480 thermal cycler (Perkin-Elmer, Norwalk, CT).

PCR assays were performed in a $25 \mu$ total volume adding the following components to the reaction tubes: $1 \mu \mathrm{l}$ of target DNA (obtained from dilutions of colonies in $50 \mu$ of $10 \mathrm{mM}$ Tris, $1 \mathrm{mM}$ EDTA - pH 8.0 (Sigma), $1.5 \mathrm{mM}$ $\mathrm{MgCl}_{2}$ (Invitrogen), 0,2 mM of dNTP mixture (dATP, dTTP, dCTP and dGTP) (Invitrogen), 20 pmol of each primer (Invitrogen), 1x PCR buffer (Promega), and $1.25 \mathrm{U}$ of Taq DNA Polymerase (Invitrogen).

The amplified products were subjected to electrophoresis in a $1.5 \%$ agarose gel (Sigma). Table 1 shows all primers used in the PCR reactions and the expected amplicon sizes.

Table 1. Primers used on the PCR assays for EMA, ESBL, and PMQR encoding genes detection

\begin{tabular}{llcc}
\hline Primer & Sequence 5' $\quad$ 3' $\longrightarrow$ & Amplicon size & Reference \\
\hline Acc3lla-F & ACT GTG ATG GGA TAC CGC TC & 237 bp & $(28)$ \\
Acc3lia-R & CTC CGT CAG CGT TTC AGC TA & & \\
TEM-F & TTG GGT GCA CGA GTG GGT TA & $503 \mathrm{bp}$ & $(26)$ \\
TEM-R & TAA TTG TTG CCG GGA AGC TA & & \\
SHV-F & TCG GGC CGC GTA GGC ATG AT & $625 \mathrm{bp}$ & $(26)$ \\
SHV-R & AGC AGG GCG ACA ATC CCG CG & & \\
CTX-M-1-F3 & GAC GAT GTC ACT GGC TGA GC & $499 \mathrm{bp}$ & $(27)$ \\
CTX-M-1-R2 & AGC CGC CGA CGC TAA TAC A & & \\
TOHO-1-2F & GCG ACC TGG TTA ACT ACA ATC C & $351 \mathrm{bp}$ & $(27)$ \\
TOHO-1-1R & CGG TAG TAT TGT CCT TAA GCC & & \\
qnrA up & AAG GAA GCC GTA TGG ATA TT & $670 \mathrm{bp}$ & $(29)$ \\
qnrA dw & AGC TAA TCC GGC AGC ACT AT & & \\
qnrB up & CGA CCT GAG CGG CAC TGA AT & $515 \mathrm{bp}$ & $(29)$ \\
qnrB dw & TGA GCA ACG ATG CCT GGT AG & & \\
qnrS up & ACC TTC ACC GCT TGC ACA TT & $509 \mathrm{bp}$ & $(29)$ \\
qnrS dw & CCA GTG CTT CGA GAA TCA GT & & \\
KPC-F & TGT CAC TGT ATC GCC GTC & $1011 \mathrm{bp}$ & $(30)$ \\
KPC-R & CTC AGT GCT CTA CAG AAA AAC C & & \\
\hline
\end{tabular}

\section{Results}

\section{Strain isolation from clinical material}

We isolated five strains of $K$. pneumoniae subsp. pneumoniae and five strains of $E$. coli from the EMB media containing gentamicin.

\section{Strain isolation from water samples}

We isolated 17 E. coli, four K. pneumoniae subsp. pneumonia, and one $K$. pneumoniae subsp. ozaenae from the media containing gentamicin 
and four E. coli and one K. pneumoniae subsp. ozaenae from the media containing cephalotin.

\section{Antimicrobial susceptibility testing and ESBL confirmation test}

To determine the resistance profiles of all isolated strains we used different classes of antimicrobial drugs ranging from those first used in therapeutics to the latest introduced in the medical practice.

There were some differences between strains isolated from media supplemented with gentamicin and those isolated from media supplemented with cephalotin in the water samples. Of the isolates obtained from gentamicin media, eight (36.4\%) were resistant to cephalotin on the AST and of those obtained from cephalotin media, two (40\%) were resistant to gentamicin on the AST. In water isolates, ten (37\%) showed multidrug-resistance profiles similar to those displayed by clinical isolates, i.e., they were resistant to drugs used specifically in healthcare settings.

Twelve isolates were tested to confirm the presence of ESBL enzymes and $11(91.7 \%)$ of them were positive. Fourteen (51.8\%) showed resistance to ciprofloxacin and norfloxacin, four (14.8\%) to amikacin, and one from Caceribu River and one from the Mage Channel were resistant to cefepime, a fourth generation cephalosporin usually used exclusively in hospitals. Furthermore, four isolates from Bica beach, one from the Mangue channel, and two from Fundão Island II were all resistant to cefepime. One K. pneumoniae subsp. ozaenae isolate, also from Fundão Island II, was resistant to ertapenem.

Table 2 presents information regarding water isolates, such as the collection site, the most relevant environmental parameters, and the antimicrobial resistance profile.

Regarding the clinical isolates, eight (80\%) showed a multidrug-resistant profile typical in hospital settings. All ten isolates were resistant to amikacin, five $(50 \%)$ were sensitive to chloramphenicol, six $(60 \%)$ exhibited resistance to ciprofloxacin and norfloxacin, and four (40\%) isolates were resistant to cefepime. Additionally, three (30\%) isolates showed resistance to imipenem and ertapenem, which may indicate carbapenemases production, and five (50\%) indicated ESBL production.

Table 3 shows information regarding clinical isolates, such as the sample type, the hospital ward, and the antimicrobial resistance profile.

\section{Plasmid DNA extraction}

All strains isolated from water and nine $(90 \%)$ strains isolated from clinical samples had at least one plasmid band.

\section{Polymerase chain reaction (PCR)}

Of all the water isolates collected at the Guanabara Bay, nine (37.5\%) showed PCR amplicon specific to EMA, two (18.2\%) only for ESBL, and one (16.6\%) for PMQRs. Seven (63.3\%) isolates had positive amplification for both EMA and ESBL encoding genes. Two (7.4\%) showed the presence of EMA, ESBL, and PMQR encoding genes (table 4).

Of the clinical isolates, two (20\%) showed gene amplification for EMA and only one $(20 \%)$ for ESBL. Three $(60 \%)$ isolates presented an amplicon for 
both EMA and ESBL; one (16\%) for ESBL and PMQR, and two (20\%) had PCR positive results for all EMA, ESBL, and PMQR encoding genes (table 5).

\section{Discussion}

The number of bacterial strains resistant to antimicrobial drugs has been increasing considerably in the natural environment due to the vast use of these drugs in hospitals and in the community, as well as in animal husbandry and veterinary care. The problem has increased due to hospital sewage dumping in natural environments, particularly in bodies of water, which facilitates the dissemination of bacterial strains harboring resistant and virulent mechanisms throughout them and may contribute to an outbreak of massive proportions, as well as the dissemination of mobile genetic elements carrying resistant genes and concomitant virulent genes.

Water sample collection was performed in two different areas of the Guanabara Bay which are substantially distinct from each other as regards

Table 2. Enterobacteriaceae isolated from water on the different collection sites at the Guanabara Bay including their resistance profiles

\begin{tabular}{|c|c|c|c|c|}
\hline Collection site & $\begin{array}{l}\text { Phosphorus } \\
(\mu \mathrm{M} / \mathrm{L})\end{array}$ & Strain & Resistance profiles & $\begin{array}{l}\text { Confirmatory test } \\
\text { for ESBL }\end{array}$ \\
\hline \multirow[t]{5}{*}{ Guapimirim River } & 2,4 & Ec $1 \mathrm{~Gb}$ & Cph/Amp/Cip/Nor/Tet/Gen/Tob & NT \\
\hline & & Ec $1 \mathrm{Ge}$ & Amp/Gen/Kan & NT \\
\hline & & Ec $1 \mathrm{Gf}$ & Tet/Gen/Ami & NT \\
\hline & & Ec 1Cfld & $\mathrm{Cfl} / \mathrm{Cfz} / \mathrm{Cro} / \mathrm{Ctx} / \mathrm{Amp} / \mathrm{Cip} / \mathrm{Nor} / \mathrm{Tet} / \mathrm{Amc} / \mathrm{Sut}$ & $(-)$ \\
\hline & & $\mathrm{Kp} 1 \mathrm{Gd}$ & Amp/Cip/Nor/Tet/Chl/Gen/Kan/Tob & NT \\
\hline \multirow[t]{6}{*}{ Caceribu River } & 8,6 & Ec 2Ga1 & Amp/Gen/Kan/Tob & NT \\
\hline & & Ec $2 \mathrm{Ga} 2$ & Amp/Gen/Ak & NT \\
\hline & & Ec $2 \mathrm{Gc}$ & Amp/Cip/Nor/Gen & NT \\
\hline & & Ec 2CFLd & $\mathrm{Cph} / \mathrm{Cfz} / \mathrm{Cro} / \mathrm{Crx} / \mathrm{Ctx} / \mathrm{Amp}$ & $(+)$ \\
\hline & & $\mathrm{Kp} 2 \mathrm{Ge}$ & $\mathrm{Cph} / \mathrm{Cfz} / \mathrm{Cro} / \mathrm{Crx} / \mathrm{Ctx} / \mathrm{Cpm} / \mathrm{Atm} / \mathrm{Amp} / \mathrm{Cip} / \mathrm{Nor} / \mathrm{Tet} / \mathrm{Gen} / \mathrm{Amc} / \mathrm{Sut}$ & $(+)$ \\
\hline & & Kp 2Gf & Amp/Tet/Gen & NT \\
\hline \multirow[t]{2}{*}{ Guaxindiba River } & 3,2 & Ec 4Ga1 & Tet/Gen & NT \\
\hline & & Ec $4 \mathrm{Ge}$ & $\begin{array}{l}\mathrm{Cph} / \mathrm{Cfz} / \mathrm{Cro} / \mathrm{Crx} / \mathrm{Ctx} / \mathrm{Caz} / \mathrm{Cpm} / \mathrm{Atm} / \mathrm{Amp} / \mathrm{Cip} / \mathrm{Nor} / \mathrm{Tet} / \mathrm{Chl} / \mathrm{Gen} / \\
\mathrm{Kan} / \mathrm{Tob} / \mathrm{Ppt} / \mathrm{Amc} / \mathrm{Sut}\end{array}$ & $(+)$ \\
\hline \multirow[t]{2}{*}{ Fundão Island I } & 13,2 & Ec $5 \mathrm{Ga}$ & Amp/Tet/Gen/Kan & NT \\
\hline & & Ec $5 \mathrm{Gd}$ & Amp/Cip/Nor/Tet/Gen/Kan & NT \\
\hline \multirow[t]{3}{*}{ Fundão Island II } & 49,7 & Ec $6 \mathrm{Ga}$ & Amp/Cip/Nor/Tet/Chl/Gen & NT \\
\hline & & Ko 6Gb & $\begin{array}{l}\mathrm{Cph} / \mathrm{Cfz} / \mathrm{Cro} / \mathrm{Crx} / \mathrm{Ctx} / \mathrm{Caz} / \mathrm{Cpm} / \mathrm{Atm} / \mathrm{Amp} / \mathrm{Cip} / \mathrm{Nor} / \mathrm{Tet} / \mathrm{Gen} / \\
\mathrm{Kan} / \mathrm{Tob} / \mathrm{Amc} / \mathrm{Sut}\end{array}$ & $(+)$ \\
\hline & & Ko 6CFL & $\begin{array}{l}\mathrm{Cph} / \mathrm{Cfz} / \mathrm{Cro} / \mathrm{Crx} / \mathrm{Ctx} / \mathrm{Caz} / \mathrm{Cpm} / \mathrm{Atm} / \mathrm{lpm} / \mathrm{Etp} / \\
\text { Amp/Cip/Nor/Tet/Gen/Kan/Tob/Ppt/Amc/Asb/ } \\
\text { Sut }\end{array}$ & $(+)$ \\
\hline \multirow[t]{4}{*}{ Bica beach } & 19,5 & Ec $7 \mathrm{Ga}$ & $\begin{array}{l}\mathrm{Cph} / \mathrm{Cfz} / \mathrm{Cro} / \mathrm{Crx} / \mathrm{Ctx} / \mathrm{Cpm} / \mathrm{Amp} / \mathrm{Cip} / \text { Nor/Tet/ } \\
\mathrm{Chl} / \mathrm{Gen} / \mathrm{Tob} / \mathrm{Amc} / \mathrm{Sut}\end{array}$ & $(+)$ \\
\hline & & Ec $7 \mathrm{~Gb}$ & $\begin{array}{l}\mathrm{Cph} / \mathrm{Cfz} / \mathrm{Cro} / \mathrm{Crx} / \mathrm{Cpm} / \mathrm{Atm} / \mathrm{Amp} / \mathrm{Cip} / \mathrm{Nor} / \mathrm{Tet} / \\
\mathrm{Chl} / \mathrm{Gen} / \mathrm{Amc} / \mathrm{Asb} / \mathrm{Sut}\end{array}$ & $(+)$ \\
\hline & & Ec $7 \mathrm{Gc}$ & $\begin{array}{l}\text { Cph/Cfz/Cro/Crx/Ctx/Cpm/Atm/Amp/Cip/Nor/ } \\
\text { Tet/Chl/Gen/Ami/Amc/Sut }\end{array}$ & $(+)$ \\
\hline & & Ec 7CFLd & $\begin{array}{l}\mathrm{Cph} / \mathrm{Cfz} / \mathrm{Cro} / \mathrm{Crx} / \mathrm{Ctx} / \mathrm{Cpm} / \mathrm{Atm} / \mathrm{Amp} / \mathrm{Cip} / \mathrm{Nor} / \\
\mathrm{Tet} / \mathrm{Chl} / \mathrm{Gen} / \mathrm{Amc} / \mathrm{Sut}\end{array}$ & $(+)$ \\
\hline Mangue Channel & 64,6 & Kp 8b1 & $\begin{array}{l}\mathrm{Cph} / \mathrm{Cfz} / \mathrm{Cro} / \mathrm{Crx} / \mathrm{Ctx} / \mathrm{Caz} / \mathrm{Atm} / \mathrm{Amp} / \mathrm{Cip} / \mathrm{Nor} / \\
\mathrm{Tet} / \mathrm{Gen} / \mathrm{Kan} / \mathrm{Tob}\end{array}$ & $(+)$ \\
\hline
\end{tabular}

Ec: E. coli; Kp- K. pneumoniae; Ko: K. pneumoniae subsp. ozaenae; Cph: Cephalotin; Cfz: Cephazolin; Cro: Ceftriaxone; Crx: Cefuroxime; Ctx: Cefotaxime; Caz: Ceftazidime; Cpm: Cefepime; Atm: Aztreonam; Ipm: Imipenem; Etp: Ertapenem; Amp: Ampicillin; Cip: Ciprofloxacin; Nor: Norfloxacin; Tet: Tetracycline; Chl: Chloramphenicol; Gen: Gentamicin; Ak: Amikacin; Kan: Kanamycin; Tob: Tobramycin; Ppt: Piperacillin/tazobactam; Amc: Amoxillin/clavulanic acid; Asb: Ampicillin/sulbactam; Sut: Cotrimoxazol; NT: not tested 
Table 3. Enterobacteriaceae isolated from clinical samples including their resistance profiles

\begin{tabular}{|c|c|c|c|c|}
\hline Unit & Sample & Strain & Resistance profiles & $\begin{array}{l}\text { Confirmatory test } \\
\text { for ESBL }\end{array}$ \\
\hline \multirow[t]{4}{*}{ Ambulatory } & Urine & Ec 1407 & Amp/Cip/Nor/Tet/Gen/Tob/Sut & NT \\
\hline & & EC 1419 & $\mathrm{Cfl} / \mathrm{Cfz} / \mathrm{Cro} / \mathrm{Crx} / \mathrm{Ctx} / \mathrm{Nor} / \mathrm{Tet} / \mathrm{Clo} / \mathrm{Gen}$ & $(-)$ \\
\hline & & Ec 1798 & $\mathrm{Cph} / \mathrm{Cfz} / \mathrm{Cro} / \mathrm{Crx} / \mathrm{Ctx} / \mathrm{Caz} / \mathrm{Cpm} / \mathrm{Atm} / \mathrm{Amp} / \mathrm{Tet} / \mathrm{Chl} / \mathrm{Gen} / \mathrm{Kan} / \mathrm{Tob} / \mathrm{Asb} / \mathrm{Sut}$ & $(+)$ \\
\hline & & Ec 2383 & Amp/Cip/Nor/Tet/Gen/Sut & NT \\
\hline $\begin{array}{l}\text { Thoracic } \\
\text { surgery clinic }\end{array}$ & Pleural fluid & Ec $1633 a$ & $\mathrm{Cph} / \mathrm{Cfz} / \mathrm{Crx} / \mathrm{Caz} / \mathrm{Amp} / \mathrm{Cip} / \mathrm{Nor} / \mathrm{Chl} / \mathrm{Gen} / \mathrm{Kan} / \mathrm{Tob} / \mathrm{Asb} / \mathrm{Sut}$ & $(+)$ \\
\hline ICU & Secretion & Kp 2141b & Cph/Cfz/Cro/Fox/Crx/Caz/Atm/lpm/Etp/Amp/Gen/Kan & $(+)$ \\
\hline MC unit & Blood & Kp 2492 & $\mathrm{Cph} / \mathrm{Cfz} / \mathrm{Cro} / \mathrm{Crx} / \mathrm{Ctx} / \mathrm{Amp} / \mathrm{Tet} / \mathrm{Gen} / \mathrm{Sut}$ & $(+)$ \\
\hline IPD unit & Urine & Kp 2692 & $\mathrm{Cph} / \mathrm{Cfz} / \mathrm{Cro} / \mathrm{Crx} / \mathrm{Ctx} / \mathrm{Cpm} / \mathrm{Amp} / \mathrm{Cip} / \mathrm{Nor} / \mathrm{Tet} / \mathrm{Gen} / \mathrm{Kan} / \mathrm{Tob} / \mathrm{Sut}$ & $(+)$ \\
\hline \multirow[t]{2}{*}{ Nephrology } & Peritoneal fluid & Kp 7438 & $\begin{array}{l}\mathrm{Cph} / \mathrm{Cfz} / \mathrm{Cro} / \mathrm{Crx} / \mathrm{Ctx} / \mathrm{Cpm} / \mathrm{Atm} / \mathrm{Imp} / \mathrm{Etp} / \mathrm{AMP} / \mathrm{Atm} / \mathrm{Imp} / \mathrm{Etp} / \mathrm{Amp} / \mathrm{Cip} / \mathrm{Nor} / \\
\mathrm{Tet} / \mathrm{Chl} / \mathrm{Gen} / \mathrm{Tob} / \mathrm{Ppt} / \mathrm{Asb} / \mathrm{Sut}\end{array}$ & $(-)$ \\
\hline & $\begin{array}{l}\text { End portion of } \\
\text { Tenckhoff catheter }\end{array}$ & Kp 7474 & $\begin{array}{l}\mathrm{Cph} / \mathrm{Cfz} / \mathrm{Cro} / \mathrm{Fox} / \mathrm{Crx} / \mathrm{Ctx} / \mathrm{Cpm} / \mathrm{Atm} / \mathrm{Imp} / \mathrm{Etp} / \mathrm{Amp} / \mathrm{Cip} / \mathrm{Nor} / \mathrm{Tet} / \mathrm{Chl} / \mathrm{Gen} / \\
\text { Tob/Ppt/Asb/Sut }\end{array}$ & $(-)$ \\
\hline
\end{tabular}

Ec: E. coli; Kp: K. pneumoniae; ICU: Intensive care unit; MC: Medical clinic unit; IPD: unit of infectious-parasitic diseases; Cph: Cephalotin; Cfz: Cephazolin; Cro:

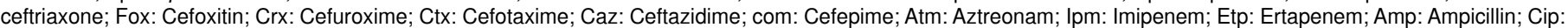

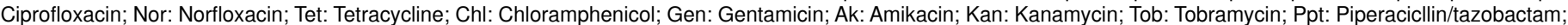
Amc: Amoxillin/clavulanic acid; Asb: Ampicillin/sulbactam; Sut: Cotrimoxazol; NT: not tested

Table 4. Genes found by PCR in the Enterobacteriaceae strains isolated from water samples

\begin{tabular}{|c|c|}
\hline Strain & Identified genes \\
\hline Ec $1 \mathrm{~Gb}$ & aacC2 \\
\hline Ec $1 \mathrm{Ge}$ & aacC2 \\
\hline $\mathrm{Kp} 1 \mathrm{Gd}$ & $q n r B$ \\
\hline Ec 2Ga1 & aacC2 \\
\hline Ec $2 \mathrm{Ga} 2$ & aacC2 \\
\hline Ec 2Gc & aacC2 \\
\hline Ec 2CFLd & blaTOHO-1 \\
\hline $\mathrm{Kp} 2 \mathrm{Ge}$ & aacC2/blaTEM/blaSHV/blaCTX-M-1 \\
\hline Kp 2Gf & aacC2 \\
\hline Ec 3CFLc & blaTOHO-1 \\
\hline Ec $4 \mathrm{Ge}$ & aacC2/blaTEM/blaCTX-M-1/qnrB \\
\hline Ec $5 \mathrm{Ga}$ & aacC2 \\
\hline Ec 5Gd & aacC2 \\
\hline Ec $6 \mathrm{Ga}$ & $\operatorname{aacC2}$ \\
\hline Ko 6Gb & aacC2/blaTEM/blaSHV/blaCTX-M-1 \\
\hline Ko 6CFL & aacC2/blaTEM/blaSHV/blaCTX-M-1 \\
\hline $\mathrm{Ec} 7 \mathrm{Ga}$ & aacC2/blaTEM/blaCTX-M-1 \\
\hline Ec $7 \mathrm{~Gb}$ & aacC2/blaTEM/blaCTX-M-1 \\
\hline Ec 7Gc & aacC2/blaTEM/blaCTX-M-1 \\
\hline Ec 7CFLd & aacC2/blaTEM/blaCTX-M-1 \\
\hline $\mathrm{Kp} 8 \mathrm{~b}^{1}$ & aacC2/blaTEM/blaCTX-M-1/qnrB \\
\hline
\end{tabular}

Ec: E. coli; Kp: K. pneumoniae; Ko: K. pneumoniae subsp. ozaenae

their ecology and preservation practices and legislation. In the protected area of Guapimirim, the quality of water is supposed to be good for human consumption and recreation and the mangrove should be well preserved. Differently, the Fundão and Governador Islands are known to be strongly affected by massive discharges of treated and untreated human and animal sewage due to the vast population living in their surroundings. 
Table 5. Genes found by PCR in the Enterobacteriaceae strains isolated from clinical samples

\begin{tabular}{ll}
\hline Strain & Identified genes \\
\hline Ec 1407 & aacC2 \\
Ec 1798 & aacC2/ blaTEM/blaCTX-M-1 \\
Ec 2383 & aacC2 \\
Ec 1633a & blaTEM/ blaTOHO-1/ qnrA \\
Kp 2141b & blaTOHO-1 \\
Kp 2492 & aacC2/ blaTEM/ blaCTX-M-1/ blaTOHO-1 \\
Kp 2692 & aacC2/ blaTEM/blaSHV/ blaCTX-M-1 \\
Kp 7438 & aacC2/ qnrB/ blaKPC \\
Kp 7474 & aacC2/ qnrB/blaKPC \\
\hline
\end{tabular}

Ec: E. coli; Kp: K. pneumoniae

No differences were noticed between the resistance profiles in the isolates from the Guapimirim area, Fundão and Governador Islands, and the Mangue Channel, although Guapimirim isolates showed less diverse resistance profiles in the different antimicrobial classes. In all the collection sites within the Guapimirim area, there was at least one isolate showing a resistance profile compatible with hospital strains which are known to be exposed to stronger antimicrobial drugs.

According to Negreiros, et al. (31), population growth and industry development, including pharmaceutical industries, affecting these bodies of water have contributed to their degradation. The authors also state that there is a massive agricultural activity in the vicinities of these bodies of water. Besides its privileged geographical location, these areas have been affected by the lack of sewage treatment infrastructures and policies unable to fulfill the demand of population growth. The majority of multidrug-resistant strains were, as expected, isolated in the areas with higher human impact.

It is not possible to discard that bacteria with resistant genes enclosed in plasmids may be disseminated to the bodies of water and that humans might be colonized with these strains when they use the water for consumption, recreational or professional reasons $(32,33)$. Prado, et al. $(34)$, demonstrated the presence of $K$. neumonia multidrug-resistant strains in water samples collected from hospital sewage treatment facilities. They found that almost $50 \%$ of the isolates were positive for beta-lactamic enzyme production and, within this group, $70 \%$ were resistant to gentamycin and $10 \%$ to ciprofloxacin. In the present study, $80 \%$ of the water isolates were positive for $E$. coli and of these, $52 \%$ was collected in the Guapimirim protected area and, besides, some multidrug-resistant isolates were found, which may indicate that these areas are being subjected to untreated dumping.

Regarding the clinical isolates, the use of selective agar media supplemented with gentamycin did not allow for the isolation of an enormous amount of isolates, although a high percentage of multidrug resistance was observed. According to Magiorakos, et al. (35), resistance to gentamycin may indicate a multidrug-resistant profile.

The water isolates from all the sites exhibited plasmids with different weights, even those strains with intrinsic resistance which were not submitted to antimicrobial pressure. Likewise, clinical isolates presented plasmids with different weights. Vaydia's (14) study on E. coli and $K$. neumonia of clinical origin containing plasmids and showing resistance to beta-lactamic and other antimicrobials identified by conjugation the transference of genes encoding those traits. 
In this study, we detected by PCR the presence of genes encoding resistance to the antimicrobial groups proposed for analysis. The water isolates $\mathrm{Ec} 4 \mathrm{Ge}$ and $\mathrm{Kp} 8 \mathrm{~Gb}_{1}$, collected at Mage and Mangue Channels showed genes encoding for resistance to the three groups of antimicrobial drugs, as well as the isolates Kp 7438 and Kp7474 collected from peritoneal fluid and the exit site of Tenckhoff catheter, respectively.

Previous studies have described the existence of Enterobacteriaceae strains isolated from food, water, and clinical specimens associated to human infections, which harbor genes encoding resistance to different antimicrobial classes, as well as genes encoding for the same antimicrobial class. Ryu, et al. (36), reported on the presence of integrons containing genes which encode resistance to ESBLs, EMAs, and tetracycline in E. coli strains isolated from meat fish and seafood in Korea. In clinical specimens in Korea, Shin, et al. (2), isolated $E$. coli and $K$. neumonia strains resistant to aminoglycosides (including gentamycin) harboring genes encoding for ESBLs and PMQRs associated with integrons enclosed in plasmids transferable by conjugation.

Gene aacC2 was detected in $58.3 \%$ of the water isolates and $70 \%$ of the clinical isolates. Gonçalves, et al. (37), detected this gene in clinical isolates containing a transposon and insertion sequences (IS), which may indicate that this gene is vastly disseminated in hospital settings, water, soil, and natural environment. Genes found in bacteria isolated from water and animals are similar to those found in pathogenic bacteria isolated from clinical specimens; furthermore, mobile genetic elements, such as integrons and transposons, are certainly involved in their transfer.

All ESBL-positive water isolates in the confirmatory test had at least one ESBL-encoding gene amplified by PCR. Encoding genes for ESBL production are generally the same in isolates from natural environments, animals, and humans. Coque, et al. (38), highlighted the need for environmental surveillance to identify bacterial clones capable of producing ESBLs in the community and the natural environment.

Isolate Koz 6CFL from a water sample collected at Fundão Island II

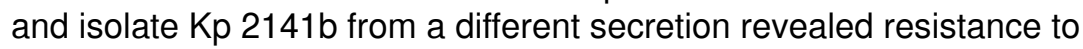
fourth-generation cephalosporin and to carbapenems in the AST, but the confirmatory test for carbapenem-enzyme production and PCR for bla ${ }_{K P C}$, were negative. Thus, resistance to imipenem and ertapenem seem to be associated with other resistance mechanisms. In the strains expressing resistance to fourth generation cephalosporin's and carbapenems in the AST, we chose to evaluate only the presence of $b / a_{K P C}$ gene and not other genes like $b / a_{\mathrm{OXA}}, b / a_{\mathrm{IMP}}$, and $b / a_{\mathrm{NDM}}$. The $b l a_{K P C}$ gene was initially detected in strains of $K$. pneumoniae of hospital origin, which aroused our interest to investigate the presence of this gene in environmental strains and to compare them with strains isolated from clinical samples.

Leavitt, et al. (39) identified K. neumonia strains resistant to ertapenem which were not carbapenemases producers but instead harbored genes for CTX-M, SHV, and TEM associated with changes in the cell wall permeability due to a lack of gene expression for cell-wall membrane proteins. In the present study, isolate Koz 6CFL showed the presence of genes encoding for CTX-M, SHV, and TEM while isolate Kp 2141b only presented genes encoding for CTX-M. The existence of these encoding genes in clinical isolates would have serious consequences for antibiotic therapy, and their 
presence in environmental isolates may indicate not-treated discharges into the natural environment which may contain antimicrobial drug residues and/or bacteria carrying resistance genes in mobile genetic elements.

Strains Ec $1 \mathrm{Gd}$, Ec $4 \mathrm{Ge}$, and $\mathrm{Kp} 8 \mathrm{~Gb}$, isolated from the Guapimirim and Magé Rivers and from Mangue Channel, respectively, showed PCR results positive for qnrB gene. Takasu, et al. (40), detected the presence of qnrB in isolates from samples collected in bodies of water in Vietnam and concluded that the presence of this gene in such isolates was not associated with the use of quinolone antimicrobials in animal husbandry, aquaculture or infections control, although the existence of these genes in natura has not been proven to be intrinsic to the bacterial genome. According to Strahilevitz, et al. (41), the origins of qnr family genes were not only found in environmental bacteria but also in bacteria isolated from humans and animals. Nordmann, et al. (42), reported that qnr genes in Enterobacteriaceae can be associated to ESBLs, CTX-M-1 or CTX-M-9, which may indicate that genes encoding for beta-lactamases and quinolone resistance mechanisms may be located in the same plasmid with a possibility of transfer to other species.

The presence in hospital settings of Enterobacteriaceae strains harboring resistance genes to several classes of antimicrobial drugs or of several genes encoding for one same class is a well-established fact (43). Besides the small bacterial population analyzed in the present study, it was possible to detect a representative group with well discernible characteristics, which is occurring in hospitals all over the world. In a study by Minarini, et al. (44), Enterobacteriaceae strains harboring qnr genes were isolated from outpatients in several Brazilian states. Although the clinical isolates in this study come from inpatients, these results corroborate those reported by Minarini, et al. (44), showing that qnrB is more prevalent in Brazil than qnrA, while in the latter study, no samples from Rio de Janeiro state were studied.

Öktem, et al. (45), studying E. coli and K. pneumoniae strains isolated from blood samples showing resistance to beta-lactamic and quinolone drugs found a correlation between the plasmids containing at least one beta-lactamase encoding gene $\left(b / a_{\mathrm{TEM}}, b l a_{\mathrm{SHV}}\right.$ or $\left.b l a_{\mathrm{CTX}-\mathrm{M}}\right)$ associated with the presence of the qnrA gene. All the isolates in the study, except for Kp 2692, showed the presence of a plasmid by PCR testing. The existence of plasmids concomitantly harboring genes encoding resistance for different classes of antimicrobial drugs may promote dissemination of bacteria involved in infections of complex treatment (38).

Sewage treatment plants constitute a favorable environment for the selection and transfer of resistance genes between bacteria. Mokracka, et al. (46), studied the water from different sites at a sewage treatment plant and found $E$. coli strains containing integrons, even in samples from the end effluent, some of which even had genes encoding for different antimicrobial classes. In the present study, we found an isolate $(\mathrm{Kp} 2 \mathrm{Ge})$ from water collected at the Caceribu River containing the aacC2, bla $\mathrm{TEM}_{\mathrm{TH}}, \mathrm{bla}_{\mathrm{SH}}$, and the $\mathrm{bla}_{\mathrm{CTX}-\mathrm{M}-1}$ genes. There was also an isolate $(\mathrm{Ec} 4 \mathrm{Ge})$ from water collected at the Magé Channel that included aacC2, $b l a_{\mathrm{TEM}}, b l a_{\mathrm{CTX}-\mathrm{M}-1}$ and $q n r B$ genes. Despite the fact that the Caceribu River and the Mage Channel are part of a protected area, they have been degraded due to discharges of anthropic origin, results which were corroborated by the data from the Instituto Estadual de Meio Ambiente (INEA) (19).

Among the isolates from water samples collected in the areas of higher degradation, isolates Koz 6Gb and Koz 6CFL (from Fundão Island II) contained aacC2, bla $a_{\mathrm{TEM}}, b / a_{\mathrm{SHV}}$, and bla $\mathrm{CTX}_{\mathrm{M}-1}$ genes. Isolates Ec 7Ga, Ec 
7Gb, Ec 7Gc, and Ec 7CFLd from water samples collected at Bica beach showed the presence of aacC2, bla $a_{\mathrm{TEM}}$, and $b / a_{\mathrm{CTX}-\mathrm{M}-1}$ genes, while isolate $\mathrm{Kp} 8 \mathrm{~Gb}$ from water samples collected at the Mangue Channel harbored the aacC2, bla $a_{\mathrm{TEM}}$, bla $\mathrm{CTX}-\mathrm{M}-1$, and $q n r B$ genes.

The transfer of genetic elements is occurring uninterruptedly in the hospital and the community environments either during bacterial division (vertical form) or through other mechanisms, such as bacterial conjugation (horizontal form). The selective pressure for the use of antimicrobials in these environments chooses those microorganisms that carry such elements, which will thus have the possibility of spreading to other microorganisms.

The presence of E. coli strains in water samples is an indicator of fecal contamination (47). Multidrug-resistant Enterobacteriaceae strains which colonize human and animal intestines are continuously discharged to the natural environment and may cause serious opportunistic infections behaving as reservoirs for antimicrobial-resistant genes. The genes identified in the present study indicate that the water bodies where samples were collected were exposed to sewage dumping from households, hospitals, and industries and this has prompted the presence of bacteria with the latter characteristics in these natural bodies of water.

We want to emphasize that the use of adequate procedures such as the proper use of antimicrobial drugs in hospitals, veterinary care, and aquaculture, may contribute to more efficient control of the dissemination of bacteria harboring plasmids containing genes encoding for antimicrobialresistance mechanisms. It is clear that there is a need for a committed effort to sustain efficient microbiological monitoring and to prevent the discharges of antimicrobial drugs residues and bacteria into the natural environment. It is also paramount to detect multidrug-resistant bacteria in bodies of water given that this is an efficient way of disseminating bacteria and the traits they may carry.

\section{Acknowledgments}

We want to thank Fiocruz/LAPIH/IOC/Brazil, especially Ana Paula D'Alincourt Carvalho Assef and Polyana Pereira for performing the KPC PCR, and Dr. Julio César Delgado Correal (Hospital Universitário Pedro Ernesto HUPE/UERJ) for the Spanish version of the abstract.

\section{References}

1. Ramphal R, Ambrose PG. Extended-spectrum $\beta$-lactamases and clinical outcomes: Current data. Clin Infect Dis. 2006;42(Suppl.4):S164-72. https://doi.org/10.1086/500663

2. Shin SY, Kwon KC, Park JW, Song JH, Ko YH, Sung JY, et al. Characteristics of aac(6')lb-cr gene in extended-spectrum $\beta$-lactamase-producing Escherichia coli and Klebsiella pneumoniae isolated from Chungnam area. Korean J Lab Med. 2009;29:541-50. https://doi.org/10.3343/kjlm.2009.29.6.541

3. Harada K, Morimoto E, Kataoka Y, Takahashi T. Clonal spread of antimicrobial-resistant Escherichia coli isolates among pups in two kennels. Acta Vet Scand. 2011;53:11-7. https://doi.org/10.1186/1751-0147-53-11

4. Alem N, Frikh M, Srifi A, Maleb A, Chadli M, Sekhsokh Y, et al. Evaluation of antimicrobial susceptibility of Escherichia coli strains isolated in Rabat University Hospital (Morocco). BMC Res Notes. 2015;8:392-5. https://doi.org/10.1186/s13104-015-1380-9

5. Ajiboye RM, Solberg OD, Lee BM, Raphael E, DebRoy C, Riley LW. Global spread of mobile antimicrobial drug resistance determinants in human and animal Escherichia coli and Salmonella strains causing community-acquired infections. Clin Infect Dis. 2009;49:365-71. https://doi.org/10.1086/600301 
6. Sengupta S, Chattopadhyay MK, Grossart H-P. The multifaceted roles of antibiotics and antibiotic resistance in nature. Front Microbiol. 2013;4:47. https://doi.org/10.3389/fmicb.2013.00047

7. Martínez JL. The role of natural environments in the evolution of resistance traits in pathogenic bacteria. Proc Biol Sci. 2009;276:2521-30. https://doi.org/10.1098/rspb.2009.0320

8. Bonelli RR, Moreira BM, Picão RC. Antimicrobial resistance among Enterobacteriaceae in South America: History, current dissemination status and associated socioeconomic factors. Drug Resist Updat. 2014;17:24-36. https://doi.org/10.1016/j.drup.2014.02.001

9. Bok E, Mazurek J, Stosik M, Wojciech M, Baldy-Chudzik K. Prevalence of virulence determinants and antimicrobial resistance among commensal Escherichia coli derived from dairy and beef cattle. Int J Environ Res Public Health. 2015;12:970-85. https://doi.org/10.3390/ijerph120100970

10. Resende JA, Borges ML, Pacheco KD, Ribeiro IH, Cesar DE, Silva VL, et al. Antibiotic resistance in potentially bacteriocinogenic probiotic bacteria in aquaculture environments. Aquac Res. 2017;48:2113-9. https://doi.org/10.1111/are.13047

11. Guenther S, Ewers C, Wieler LH. Extended-spectrum beta-lactamases producing E. coli in wild life, yet another form of environmental pollution? Front Microbiol. 2011;2:246. https://doi.org/10.3389/fmicb.2011.00246

12. Jones-Dias D, Manageiro V, Graça R, Sampaio DA, Albuquerque T, Themudo P, et al. QnrS1- and Aac(6')-lb-cr-Producing Escherichia coli among isolates from animals of different sources: Susceptibility and genomic characterization. Front Microbiol. 2016;7:671. https://doi.org/10.3389/fmicb.2016.00671

13. Giedraitienè A, Vitkauskienè A, Naginienè R, Pavilonis A. Antibiotic resistance mechanisms of clinically important bacteria. Medicina (Kaunas). 2011;47:137-46.

14. Vaidya VK. Horizontal transfer of antimicrobial resistance by extended spectrum $\beta$ lactamase-producing Enterobacteriaceae. J Lab Physicians. 2011;3:37-42. https://doi.org/10.4103/0974-2727.78563

15. Lyimo B, Buza J, Subbiah M, Temba S, Kipasika H, Smith W, et al. IncF plasmids are commonly carried by antibiotic resistant Escherichia coli isolated from drinking water sources in Northern Tanzania. Int J Microbiol. 2016;2016:3103672. https://doi.org/10.1155/2016/3103672

16. Ibekwe AM, Murinda SE, Graves AK. Microbiological evaluation of water quality from urban watersheds for domestic water supply improvement. Int J Environ Res Public Health. 2011;8:4460-76. https://doi.org/10.3390/ijerph8124460

17. Bayram A, Önsoy H, Bulut VN, Akinci G. Influences of urban wastewaters on the stream water quality: A case study from Gumushane Province, Turkey. Environ Monit Assess. 2013;185:1285-303. https://doi.org/10.1007/s10661-012-2632-y

18. Derrien M, Jardé E, Gruau G, Pourcher AM, Gourmelon M, Jadas-Hécart A, et al. Origin of fecal contamination in waters from contrasted areas: Stanols as microbial source tracking markers. Water Res. 2012;46:4009-16. https://doi.org/10.1016/j.watres.2012.05.003

19. Instituto Estadual de Meio Ambiente. A Baía de Guanabara, segunda maior baía do litoral brasileiro, possui uma área de cerca de $380 \mathrm{~km}^{2}$, englobando praticamente toda a Região Metropolitana do Estado do Rio de Janeiro. Accessed: February 15, 2018. Available at: http://www.inea.rj.gov.br/Portal/MegaDropDown/Monitoramento/Qualidadedaagua/Baias/ BaiadaGuanabara/index.htm

20. Meirelles-Pereira F, Meirelles AS, Gomes-da-Silva MC, Gonçalves VD, Brum PR, Castro EA, et al. Ecological aspects of the antimicrobial resistance in bacteria of importance to human infections. Braz J Microbiol. 2002;33:287-93. https://doi.org/10.1590/S1517-83822002000400002

21. Environment Protection Authority. EPA Guidelines: Regulatory monitoring and testing water and wastewater sampling. Adelaide, SA: EPA; 2007

22. Winn W, Allen S, Janda W, Koneman E, Gary P, Screckenberger P, et al. Koneman's color atlas and textbook of diagnostic microbiology. Philadelphia, New York: Lippincott Williams \& Wilkins; 2006.

23. Clinical Laboratory Standards Institute. Performance standards for antimicrobial susceptibility testing. Twenty-fourth Informational Supplement M100-S24. Wayne, PA: CLSI; 2014.

24. Clinical Laboratory Standards Institute. Performance standards for antimicrobial disk susceptibility testing. Approved Standard CLSI Document M2. Wayne, PA: CLSI; 2010. 
25. Gonçalves VD, Provençano AF, Espírito-Santo C, Bernardes O, Queiroz ML, Bello AR, et al. Evaluation of different protocols for detection of enterobacterial plasmids codifying for antimicrobial resistance. Sodebrás. 2013;8:9-15.

26. Arlet G, Philippon A. Construction by polymerase chain reaction and use of intragenic DNA probes for three main types of transferable beta-lactamases (TEM, SHV, CARB). FEMS Microbiol Lett. 1991;66:19-25.

27. Pitout JDD, Hossain A, Hanson ND. Phenotypic and molecular detection of CTX-M$\beta$-lactamases produced by Escherichia coli and Klebsiella spp. J Clin Microbiol. 2004;42:5715-21. https://doi.org/10.1128/JCM.42.12.5715-5721.2004

28. van de Klundert JAM, Vliengenthart JS. PCR detection of genes coding aminoglicoside-modifying enzymes. In: Persing DH, Smith TF, Tenover FC. White TJ, editors. Diagnostic molecular microbiology: Principles and applications. Rochester: Mayo Foundation; 1993. p. 547-52.

29. Jiang Y, Zhou Z, Qian Y, Wei Z, Yu Y, Hu S, et al. Plasmid-mediated quinolone resistance determinants qnr and aac(6')-Ib-cr in extended-spectrum b-lactamase-producing Escherichia coli and Klebsiella pneumoniae in China. J Antimicrob Chemother. 2008;61:1003-6. https://doi.org/10.1093/jac/dkn063

30. Yigit H, Queenan AM, Anderson GJ, Domenech-Sánchez A, Biddle JW, Steward CD, et al. Novel carbapenem-hydrolyzing $\beta$-lactamase, KPC-1, from a carbapenem-resistant strain of Klebsiella pneumoniae. Antimicrob Agents Chemother. 2001;45:1151-61. https://doi.org/10.1128/AAC.45.4.1151-1161.2001

31. Negreiros DH, Araújo FP, Coreixas MA. Nossos Rios. Niterói: Instituto Baía de Guanabara; 2002. p. 31.

32. Oliveira AJFC, França PTR, Pinto AB. Antimicrobial resistance of heterotrophic marine bacteria isolated from seawater and sands of recreational beaches with different organic pollution levels in southeastern Brazil: Evidences of resistance dissemination. Environ Monit Assess. 2010;169:375-84. https://doi.org/10.1007/s10661-009-1180-6

33. Zhao J-y, Dang H. Coastal seawater bacteria harbor a large reservoir of plasmid-mediated quinolone resistance determinants in Jiaozhou Bay, China. Microb Ecol. 2012;64:187-99. https://doi.org/10.1007/s00248-012-0008-z

34. Prado T, Pereira WC, Silva DM, Seki LM, Carvalho AP, Asensi MD. Detection of extendedspectrum b-lactamase-producing Klebsiella pneumoniae in effluents and sludge of a hospital sewage treatment plant. Lett Appl Microbiol. 2008;46:136-41. https://doi.org/10.1111/j.1472-765X.2007.02275.X

35. Magiorakos AP, Srinivasan A, Carey RB, Carmeli Y, Falagas ME, Giske CG, et al. Multidrugresistant, extensively drug-resistant and pandrug-resistant bacteria: An international expert proposal for interim standard definitions for acquired resistance. Clin Microbiol Infect. 2012;18:268-81. https://doi.org/10.1111/j.1469-0691.2011.03570.x

36. Ryu S-H, Park S-G, Choi S-M, Hwang Y-O, Ham H-J, Kim S-U, et al. Antimicrobial resistance and resistance genes in Escherichia coli strains isolated from commercial fish and seafood. Int J Food Microbiol. 2012;152:14-8. https://doi.org/10.1016/j.ijfoodmicro.2011.10.003

37. Gonçalves VD, Lengruber FB, Fonseca BO, Pereira RM, Melo LD, Lopes UG, et al. Detection and characterization of multidrug-resistant enterobacteria bearing aminoglycosidemodifying gene in a university hospital at Rio de Janeiro, Brazil, along three decades. Biomédica. 2015;35:117-24. https://doi.org/10.7705/biomedica.v35i1.2276

38. Coque TM, Baquero F, Canton R. Increasing prevalence of ESBL-producing Enterobacteriaceae in Europe. Euro Surveill. 2008;13.

Leavitt A, Carmeli Y, Chmelnitsky I, Goren MG, Ofek I, Navon-Venezia S. Molecular epidemiology, sequence types, and plasmid analyses of KPC-producing Klebsiella pneumoniae strains in Israel. Antimicrob Agents Chemother. 2010;54:3002-6. https://doi.org/10.1128/AAC.01818-09

39. Takasu H, Susuki S, Reungsang A, Viet PH. Fluoroquinolone (FQ) contamination does not correlate with occurrence of fq-resistant bacteria in aquatic environments of Vietnam and Thailand. Microbes Environ. 2011;26:135-43. https://doi.org/10.1264/jsme2.ME10204

40. Strahilevitz J, Jacoby GA, Hooper DC, Robicsek A. Plasmid-mediated quinolone resistance: A multifaceted threat. Clin Microbiol Rev. 2009;22:664-89. https://doi.org/10.1128/CMR.00016-09

41. Nordmann P, Poirel L. Emergence of plasmid-mediated resistance to quinolones in Enterobacteriaceae. J Antimicrob Chemother. 2005;56:463-9. https://doi.org/10.1093/jac/dki245 
42. Jeong HS, Bae IK, Shin JH, Kim SH, Chang CL, Jeong J, et al. Fecal colonization of Enterobacteriaceae carrying plasmid-mediated quinolone resistance determinants in Korea. Microb Drug Resist. 2011;17:507-12. https://doi.org/10.1089/mdr.2011.0040

43. Minarini LA, Poirel L, Cattoir V, Darini AL, Nordmann P. Plasmid-mediated quinolone resistance determinants among enterobacterial isolates from outpatients in Brazil. J Antimicrob Chemother. 2008;62:474-8. https://doi.org/10.1093/jac/dkn237

44. Öktem IM, Gülay Z, Bicmen M, Gür D, Gültekin M, Öğünç D, et al. qnrA prevalence in extended-spectrum $\beta$-lactamase-positive Enterobacteriaceae isolates from Turkey. Jpn J Infect Dis. 2008;61:13-7.

45. Mokracka J, Koczura R, Jabłońska L, Kaznowski A. Phylogenetic groups, virulence genes and quinolone resistance of integron-bearing Escherichia coli strains isolated from a wastewater treatment plant. Antonie Van Leeuwenhoek. 2011;99:817-24. https://doi.org/10.1007/s10482-011-9555-4

46. Kolawole OM, Ajayi KT, Olayemi AB, Okoh Al. Assessment of water quality in Asa River (Nigeria) and its indigenous Clarias gariepinus fish. Int J Environ Res Public Health. 2011;8:4332-52. https://doi.org/10.3390/ijerph8114332 